\title{
DEVELOPMENT OF HEAD AND FLOWER OF DIPSACUS SYLVESTRIS
}

CONTRIBUTIONS FROM THE HULL BOTANICAL LABORATORY 278

HILARY S. JURICA

(WITH FOURTEEN FIGURES)

\section{Introduction}

Epigyny and its occurrence among the upper Sympetalae have frequently been studied, but epigyny begins with the Rubiales, and while almost every family in this region has received attention in this regard, the Dipsaceae have been overlooked altogether. Accordingly this investigation was begun in an endeavor to fill this vacancy: During the course of the study, however, the development of the head was found to be interesting, and since it raised the question as to the relation the developing head bears to the general topography of the plant, it was thought best to include both of these phases in the present work.

For the material used in this study I am indebted to the generosity of Charles C. Deam, State Forester of Indiana, who not only collected the necessary plants at repeated intervals, but also loaned a number of mounted specimens from his herbarium. The fresh material was killed in a stock solution of chromoacetic acid and stained for the greater part with safranin, Delafield's haematoxylin, and orange $\mathrm{G}$, the latter stain being omitted in a few cases.

My acknowledgment is due to Professor Charles J. ChamberLAIN, at whose suggestion the work was undertaken, for valuable assistance rendered during the course of the investigation.

\section{General topography}

Dipsacus sylvestris is a biennial propagated by seeds. During the first season the plant develops a very flat rosette of crinkled leaves (2). These are oblong to lance-shaped, obtuse, tapering at the base and scalloped toothed. The surface of the wrinkled 
leaves is deep green, while the veins and midribs are nearly white and beset with spines. A stout taproot, often more than a foot long and with many branching rootlets, serves to anchor the plant. During the second season the flat rosette sends out a shoot, which develops into a stout, erect, and strongly ridged stem, beset with sharp spines (3), which often grows to a height of $3-6 \mathrm{ft}$., the degree of branching depending upon the richness of the soil. If viewed in cross-section, the stem is rather tough and woody, characterized by a large pith, which gradually breaks down, so that the older portions of the stem are hollow. No attempt has been made to include a study of the anatomical features. The stem leaves occur in pairs, opposite each other, with their bases so closely clasping the stem that often they are united at the base, and thus form cups which retain water (3). The clasping leaves do not make their appearance on the stem in the same plane, but observe some degree of regular alternation. Thus, if one pair of leaves is pointing north and south, the alternating pairs (the next pairs immediately above and below) point east and west (2).

According to Velenovsky (8), the axils of leaves as a rule contain an active meristem, which may give rise to new branches or axillary shoots. This is precisely what takes place in $D$. sylvestris, although with some modification. New branches or shoots do not develop from the axils of all clasping leaves, for some abortion takes place, especially in the case of plants growing in poor rocky soil. In such an environment the plants of this species are branched very little, and in some cases not at all. Whenever new shoots or branches are given off, however, they always occur in the axils of the clasping leaves. If two or more succeeding pairs of clasping leaves give rise to lateral branches, as is often the case with $D$. sylvestris found growing in a slightly better soil, the shoots make their appearance at right angles to the ones above and below. While the lateral branches are still small and scarcely noticeable, except upon closer examination, in turn they also give rise to new daughter shoots from the axils of their clasping leaves, which follow the same general plan of development as those arising from the main or central stem. Plants with secondary branches are common, whereas plants with tertiary or quarternary branching are less 
frequent, being met with generally only in more favorable environments (figs. I, 2).

The occurrence of clasping leaves on a lateral branch has considerable uniformity, at least for the individual plant. Ordinarily a lateral branch has but one pair of clasping leaves, and its
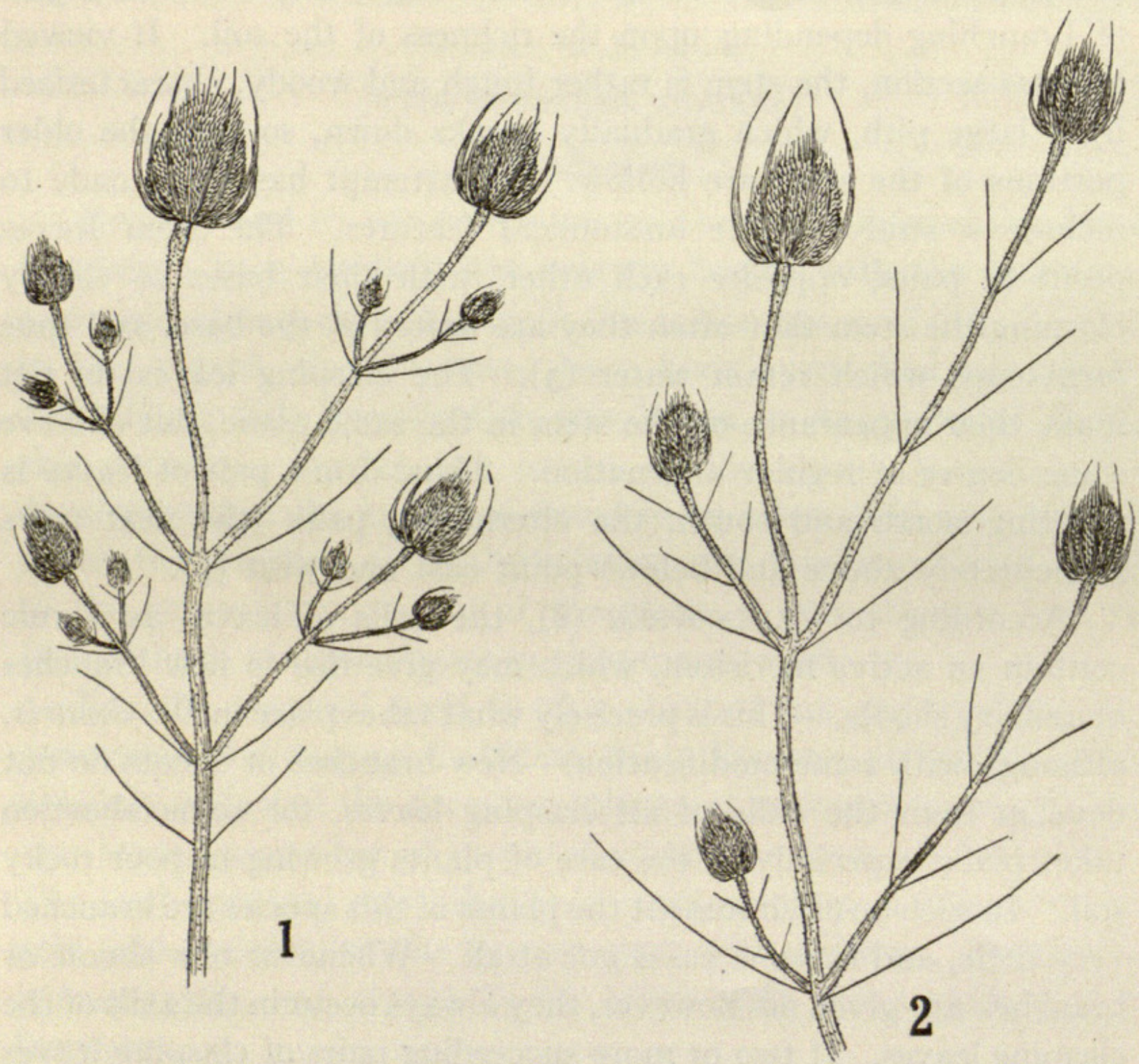

FIGS. I, 2.-Fig. I, showing general topography and mode of branching, with single pair of clasping leaves per branch; positions of leaves indicated by lines; fig. 2, plant with two pairs of clasping leaves per branch, secondary branching being absent altogether.

daughter branches likewise have but a single pair; that is, the secondary, tertiary, etc., branches, each have but one pair of clasping leaves. Plants having two pairs of clasping leaves on every branch are also characterized by a similar uniformity, consisting of the total absence of further or secondary branching 
(fig. 2). Probably the presence of an additional pair of clasping leaves per lateral branch is responsible for the total absence of secondary branching, especially since all the specimens examined showed this regularity. For the sake of certainty in this regard, however, a more extensive field study is necessary. Another noteworthy feature in regard to the development of new branches is the inequality of a developing pair. At times this inequality is so marked that a given shoot or branch happens to be three or even five times as long as its immediate neighbor, arising from the axil of the leaf directly opposite. This undoubtedly is due to the fact that the development of both members of a pair of lateral branches is not simultaneous.

\section{Floral head}

The type of inflorescence of $D$. sylvestris is a head or capitulum, surrounded by an involucre of long upcurving spiny bracts arranged in cycles of five, with the members of the outer cycle extending beyond the head, which they encircle. The bracts forming the succeeding inner cycles gradually become shorter, so much so that the members comprising the fifth inner cycle are almost equivalent in length to that of the bracts subtending the individual flowers of the head.

In its development the floral head is intimately associated with the origin of lateral or secondary branches, for the central or main stem, as well as every individual branch, is terminated by this type of inflorescence. The minute protuberance arising from the axil of a clasping leaf, and destined to develop into a new branch, is in reality a capitulum initial. Insignificant though it is at first, it immediately begins to round out, and the bracts which enter into the composition of the involucre are prompt in making their appearance (fig. 4). Almost concomitant, or at least following in close succession, are the clasping leaves of the new shoot, which appear as lateral outgrowths or papillae just below the origin of the bracts (fig. 5). As soon as the initials of these members are differentiated, the entire new shoot becomes one mass of growth. Not only does a rapid elongation of the region, both directly above and below the origin of the leaf initials, set in, but this elongation 
itself has hardly had an opportunity to proceed at all, nor have the clasping leaves developed to any extent, when in their axils an active meristem begins to give rise to the initials of another floral head. By this time the outermost cycle of bracts forming the involucre has fairly grown beyond the floral head, which they encircle, and the entire capitulum becomes one mass of protuberances, the initials of the bracts, which later subtend individual flowers.

\section{Flowers}

The flowers of $D$. sylvestris are arranged in the capitulum in the form of a low spiral, and so appear to be set in diagonal rows (figs. $3^{-14}$ ). The method of blossoming is unique. Ordinarily one would expect the blossoming to begin at the base and extend toward the tip, but the blossom tide begins at the middle and extends both ways (2). The flower itself consists of a white tube, which is divided at its end into four purple lobes. Of these four lobes the lowest is a trifle longer than the others and turns up slightly at its tip. Alternating with the lobes are four stamens, inserted on the tube of the corolla. A much reduced calyx, which encircles the base of the corolla, adheres to the inferior ovary. This typical epigynous flower is further characterized by a four-leaved calyx-like involucel, which invests the ovary and fruit (fig. I4.) The individual flowers begin their development as axial outgrowths of the bracts besetting the capitulum. This undifferentiated mass of cells, somewhat rounded at first, soon broadens a little, and the distinct lobes of the corolla appear on the peripheral portion (fig. Io). Next in appearance are the primordia of the stamens, which form the succeeding inner cycle (fig. II). Soon after this the tissue below the lobes of the corolla and stamen initials begins to elongate en masse, forming a tubular ring. Following so soon that it would almost seem to be simultaneous, is the appearance of a twofold lateral swelling just below the base of the corolla (fig. II). The upper protuberances are the primordia of the calyx and the lower develop into a calyx-like involucel, which later invests the ovary and fruit (figs. II, I4). The last to make their appearance are the carpel lobes, which appear as basal outgrowths from the inner surface of the tubular cavity (fig. I2). 


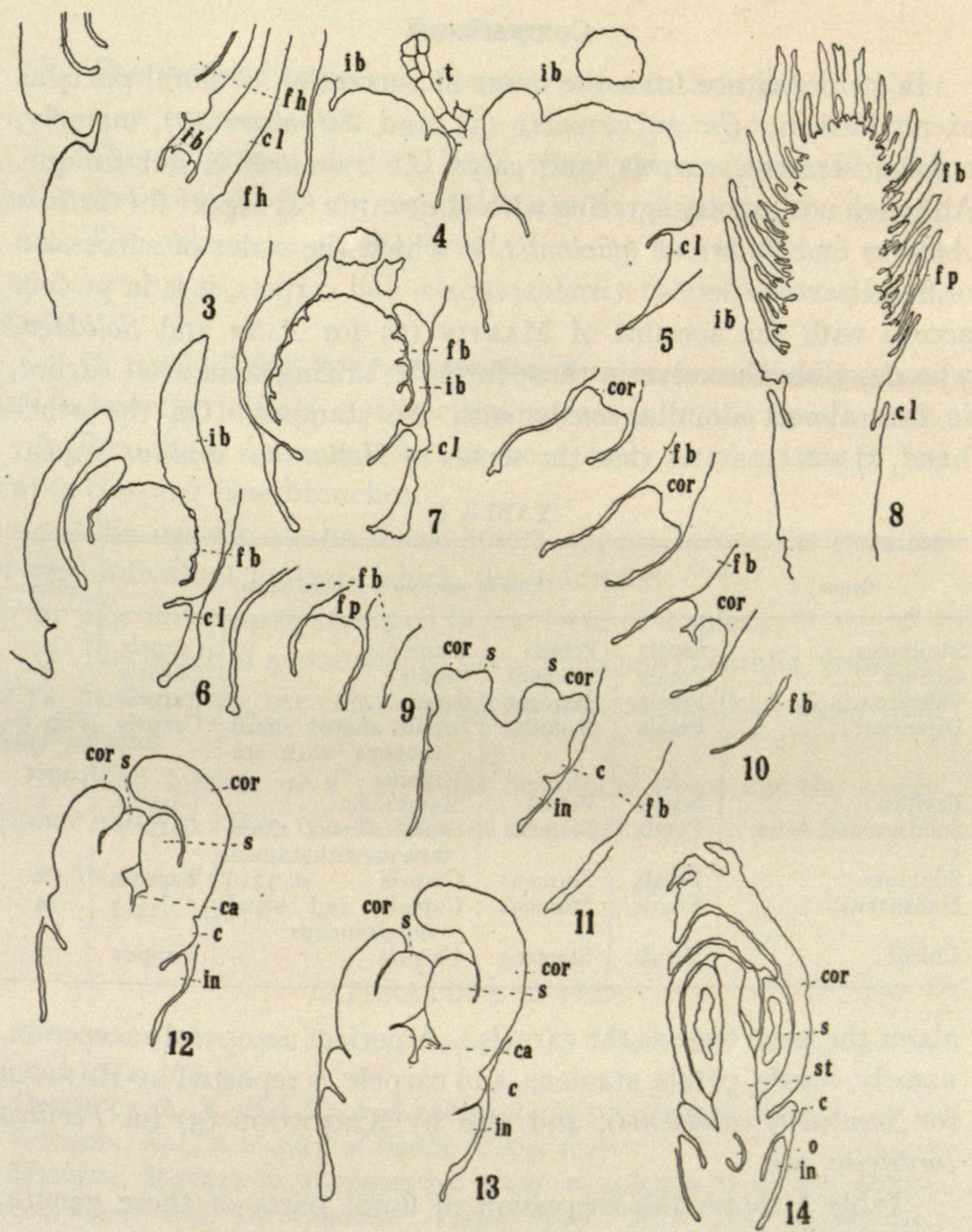

FIGS. 3-I4.-Fig. 3, longitudinal section of young floral head showing origin of another head (daughter branch) in axils of clasping leaf; fig. 4, daughter floral head enlarged showing initials of involucral bracts; $t$, trichome included to show relative size of floral head at time of origin; fig. 5, later stage of floral head showing the clasping leaf; figs. 6,7 , still later stage showing initials of individual floral bracts; fig. 8, young floral head in longitudinal section; fig. 9, papilla of single flower; fig. 10, young flower showing origin of corolla; fig. II, later stage showing beginning of stamens, calyx, and involucel; fig. 12, beginning of carpels; figs. 13, 14, later stages; abbreviations: $f h$, floral head; $c l$, clasping leaf; $i b$, involucral bract; $f b$, floral bract; $f p$, floral papilla; cor, corolla; $s$, stamen; $c$, calyx; in, involucel; st, style; $o$, ovule; ca, carpel. 


\section{Comparisons}

In its departure from the order of succession of floral parts as exemplified by Cnicus arvensis (I) and Silphium (7), namely, corolla, stamens, carpels, and calyx, D. sylvestris is not unique. Although not exactly agreeing with HANNAH's (4) report for Galium Aparine and Valeriana officinalis, in which the order of succession of floral parts is petals, stamens, sepals, and carpels, it is in perfect accord with the account of MARTIN (6) for Aster and Solidago, who describes the calyx in those forms as arising somewhat earlier, in fact almost simultaneously with the stamens. On the other hand, HANNAH states that the sepals of Helianthus annuus appear

TABLE I

\begin{tabular}{|c|c|c|c|c|c|}
\hline \multirow{2}{*}{$\frac{\text { Genus }}{\text { Sambucus........ }}$} & \multicolumn{4}{|c|}{ Order of succession of floral parts } & \multirow{2}{*}{$\begin{array}{c}\begin{array}{c}\text { Investi- } \\
\text { gator }\end{array} \\
4\end{array}$} \\
\hline & Sepals & Petals & Stamens & Carpels & \\
\hline Galium............ & Petals & Stamens & Sepals & Carpels & 4 \\
\hline Valeriana........... & Petals & Stamens & Sepals & Carpels & 4 \\
\hline Dipsacus.......... & Petals & Stamens & $\begin{array}{l}\text { Sepals almost simul- } \\
\text { taneous with sta- } \\
\text { mens }\end{array}$ & Carpels & $\begin{array}{l}\text { Figs. 9- } \\
\text { 14, this } \\
\text { paper }\end{array}$ \\
\hline Fevillea............ & Sepals & Petals & Staminodia & Carpels & 5 \\
\hline Solidago and Aster... & Petals & Stamens & $\begin{array}{l}\text { Sepals almost simul- } \\
\text { taneous with stamens }\end{array}$ & Carpels & 6 \\
\hline Silphium.... & Petals & Stamens & Carpels & Pappus & 7 \\
\hline Helianthus... & Petals & Stamens & $\begin{array}{l}\text { Carpels and sepals } \\
\text { simultaneous }\end{array}$ & & 4 \\
\hline Cnicus. & Petals & Stamens & Carpels & Pappus & $\mathbf{I}$ \\
\hline
\end{tabular}

about the same time as the carpels. A perfect acropetal succession, namely, sepals, petals, stamens, and carpels, is reported by HANNAH for Sambucus canadensis, and also by KIRKwOod (5) for Fevillea cordifolia, etc.

Table I shows the succession of floral parts of these genera, members of closely related families.

It is seen that, at least so far as the forms in which the sepals are much reduced or modified are concerned, the order of succession of floral parts is uniform for petals and stamens only. Since the primordia of either sepals or carpels may be third in appearance or even simultaneous, it is evident that a more extensive study of epigyny is necessary before any safe conclusion can be reached. 


\section{Summary}

r. The mode of branching is uniform for each individual plant.

2. New branches arise from the axils of clasping leaves.

3. The capitulum, or floral head, which terminates each branch is the first to make its appearance in the development of a branch.

4. The primordia of the bracts forming the involucre of the capitulum appear early, followed quickly by the initials of clasping leaves.

5. A twofold region of elongation sets in immediately above and below the initials of the clasping leaves of the new branch.

6. Secondary branches appear very early in the axils of the leaves clasping new branches.

7. The initials of the floral bracts appear before the papillae of the individual flowers, which they subtend.

8. The flowers are arranged in the form of a spiral.

9. The order of succession of floral members is corolla, stamens, calyx, and carpels, the calyx appearing almost simultaneously with the stamens.

Io. The initials of a calyx-like involucel investing the ovary appear shortly after the initials of the calyx.

St. Procopius College

LisLE, ILL.

\section{LITERATURE CITED}

I. Coulter, J. M., and Chamberlain, C. J., Morphology of angiosperms. I 903 (p. I7, fig. 3).

2. Comstock, A. B., Handbook of nature study, pp. 586-588. r9ir.

3. GEORGIA, AdA, A manual of weeds, p. 403. I919.

4. Hannah, Margaret, Comparative study of epigyny in certain Monocotyledons and Dicotyledons. Trans. Amer. Micr. Soc. 35:207-220. I9r6.

5. KIRKwood, J. E., The comparative embryology of the Cucurbitaceae. Bull. N.Y. Bot. Gard. 3:313-402. pls. 58, 69. 1904.

6. Martin, G. W., Development of the flower and embryo sac in Aster and Solidago. Bot. Gaz. 17:353-358, 406-4II. I892.

7. Merrell, W. D., A contribution to the life history of Silphium. Bot. GAZ. 29:99-I33. pls. 3-IO. 1900.

8. VeLENovSKY, Jos., Srovnavaci Morfologie. 2: p. 504. 1907. 


\section{$2 \mathrm{BHL}$ Biodiversity Heritage Library}

Jurica, Hilary Stanislaus. 1921. "Development of Head and Flower of Dipsacus sylvestris." Botanical gazette 71(2), 138-145. https://doi.org/10.1086/332806.

View This Item Online: https://www.biodiversitylibrary.org/item/109572

DOI: https://doi.org/10.1086/332806

Permalink: https://www.biodiversitylibrary.org/partpdf/224249

\section{Holding Institution}

Missouri Botanical Garden, Peter H. Raven Library

\section{Sponsored by}

Missouri Botanical Garden

\section{Copyright \& Reuse}

Copyright Status: Public domain. The BHL considers that this work is no longer under copyright protection.

This document was created from content at the Biodiversity Heritage Library, the world's largest open access digital library for biodiversity literature and archives. Visit BHL at https://www.biodiversitylibrary.org. 